\title{
A Preliminary Checklist of Amphibians of Ulu Paip Recreational Forest, Kedah, Malaysia
}

\author{
Shahrudin Shahriza ${ }^{1^{*}}$ and Jaafar Ibrahim ${ }^{2}$ \\ 1 School of Pharmaceutical Sciences Universiti Sains Malaysia 11800 Penang, Malaysia. \\ 2 School of Distance Education Universiti Sains Malaysia 11800 Penang, Malaysia. \\ * Corresponding author. E-mail: shahriza20@yahoo.com
}

\begin{abstract}
Surveys on amphibian species in Ulu Paip Recreational Forest, Kedah were carried out over 12 consecutive months from January 2011 to December 2011. Twenty species of frogs from 11 genera and six families were recorded to inhabit this forest. This study represents the first report of amphibian species from Ulu Paip Recreational Forest.
\end{abstract}

\section{INTRODUCTION}

Ulu Paip Recreational Forest is located in Compartment Two of Gunung Bongsu Forest Reserve in the southwestern part of the state of Kedah. This recreational forest can be accessed by road and is approximately $18 \mathrm{~km}$ from the town of Kulim and $53 \mathrm{~km}$ from Penang Island. The main drainage system, Sungai Karangan originates from Gunung Bongsu (658 $\mathrm{m}$ asl), flows through Sungai Muda and empties into the Straits of Malacca. Within the sampling area, the width of the river is approximately 5-8 m, composed of rocks and boulders and a riverbed of sand and gravel. Apart from the main river, there were ditches, small forest streams and swamps around the surveyed areas. Lowland dipterocarp forest surrounds this area but most parts of the forest were transformed into farms, orchards, rubber and oil palm plantations.

Herpetofaunal surveys have been conducted in various parts of Kedah (Norhayati et al. 2005; Ibrahim et al. 2006; Ibrahim et al. 2012a,b; Shahriza et al. 2011a,b) but until now, no such study has been conducted at Ulu Paip. Thus, in this report we present the first checklist of amphibians that occur in Ulu Paip Recreational Forest.

\section{MATERIALS AND MeTHOdS}

The amphibian species of Ulu Paip Recreational Forest, Kedah $\left(5^{\circ} 23^{\prime} \mathrm{N}, 100^{\circ} 39^{\prime} \mathrm{E}, \mathrm{ca} .100 \mathrm{~m}\right.$ asl) were surveyed monthly from January 2011 to December 2011 on 12 consecutive visits (Figure 1). Samplings were conducted from the car park and upstream for approximately 500 $\mathrm{m}$. Samplings were done in the river, along the river banks and 4-5 m away from the river banks. Microhabitats such as small forest streams, ditches, swampy areas, temporary puddles, rockpools, tree buttress, tree holes, leaf litter, rotten logs, rocks, tree branches and trunks around the areas were examined. Specimens were collected at night (20:00 to $23: 00 \mathrm{~h})$ in field parties consisting of three to four persons by active searching or chance encounters using bare hands and fish nets. Live specimens were photographed using an Olympus digital camera model SP800, euthanized using tricane, fixed with $10 \%$ formalin, stored in 70\% ethanol and deposited at the School of Pharmaceutical Sciences, Universiti Sains Malaysia for future reference. Tissue samples from several species such as Pedostibes hosii, Fejervarya limnocharis, Limnonectes blythii, L. laticeps, L. paramacrodon, Leptobrachium hendricksoni, Hylarana labialis and H. laterimaculata were also collected, stored in 95\% ethanol and deposited at the School of Pharmaceutical Sciences, USM for future DNA analysis. Identification of frog species followed Berry (1975) while taxonomic nomenclature followed Frost (2012).

\section{RESUlts}

Twenty species of frogs from 11 genera and six families were recorded from Ulu Paip Recreational Forest (Table 1). Photos of the frog species are shown in Figure 2(A-H), Figure 3(A-H) and Figure 4(A-D).

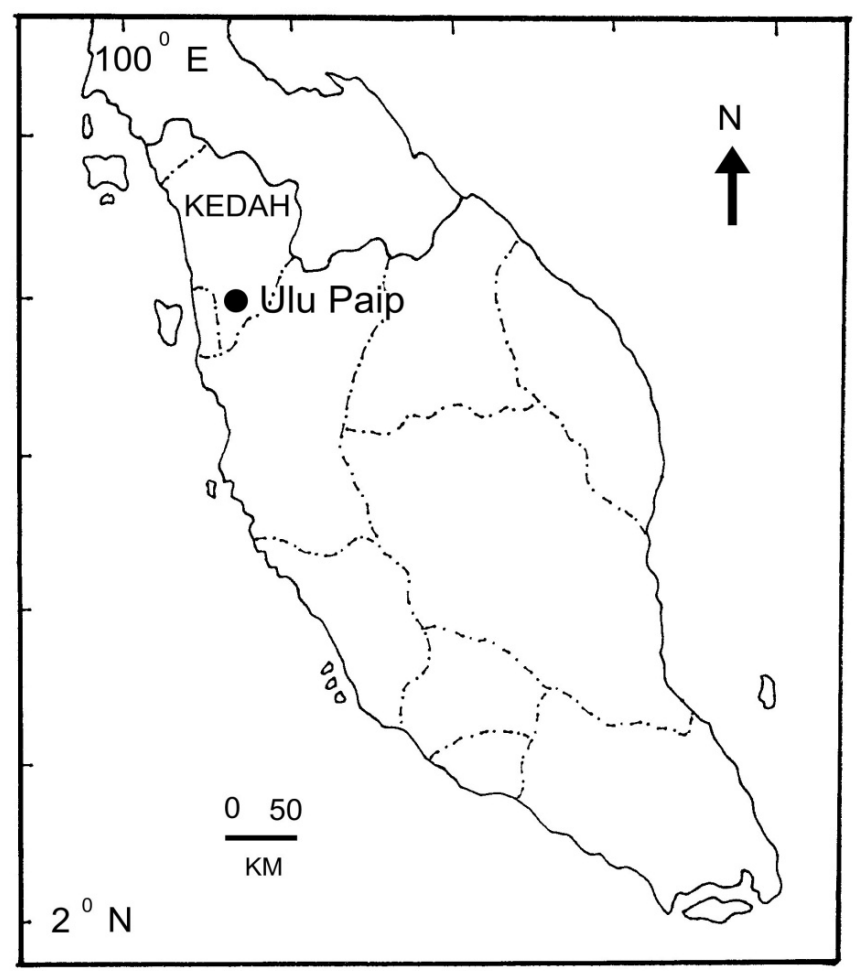

FIGURE 1. Location of Ulu Paip, Kedah. 

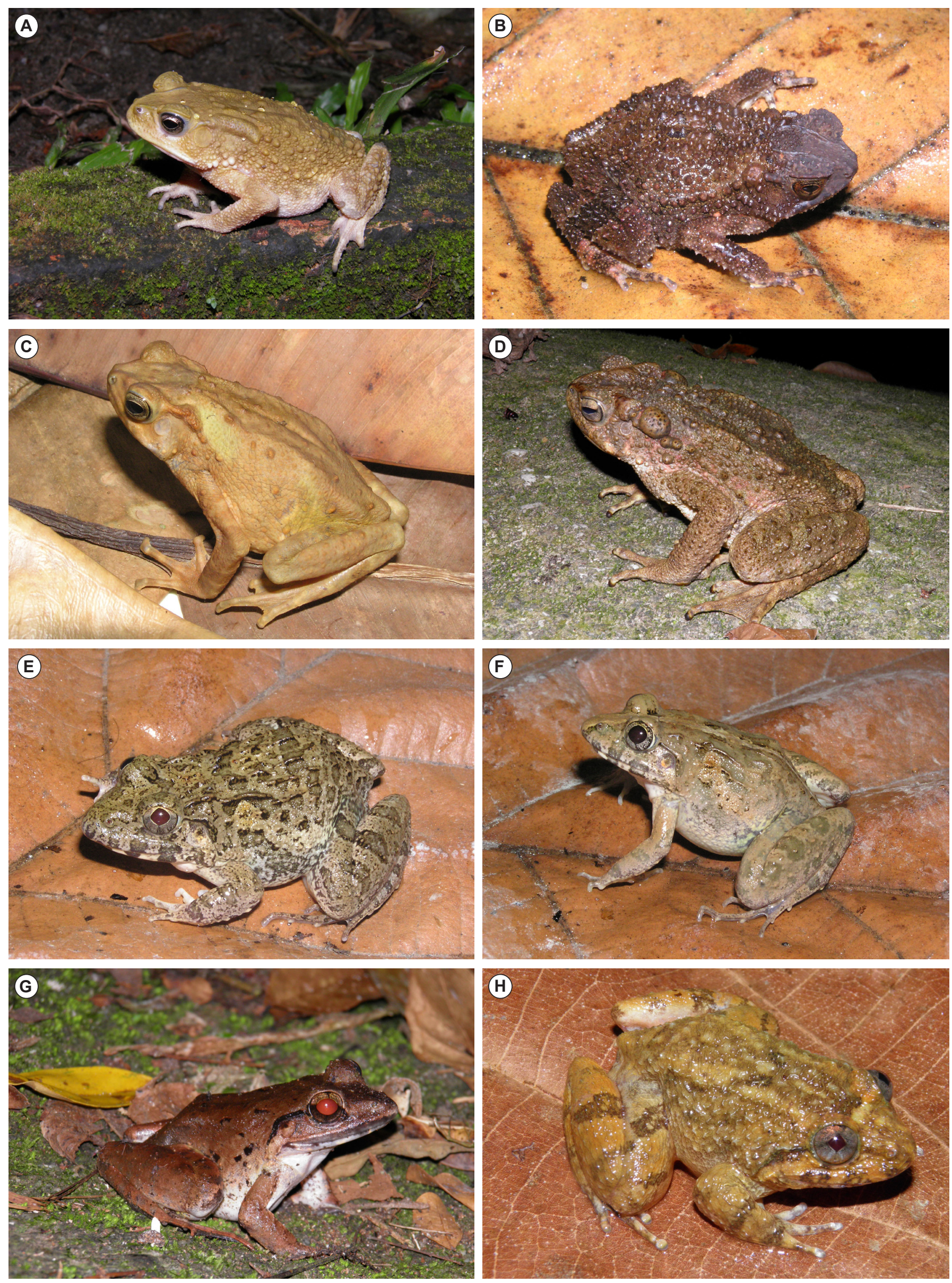

Figure 2. Some amphibian species found at Ulu Paip, Kedah. A) Duttaphrynus melanostictus; B) Ingerophrynus parvus; C) Pedostibes hosii; D) Phrynoidis aspera; E) Fejervarya cancrivora; F) Fejervarya limnocharis; G) Limnonectes blythii; H) Limnonectes laticeps. 

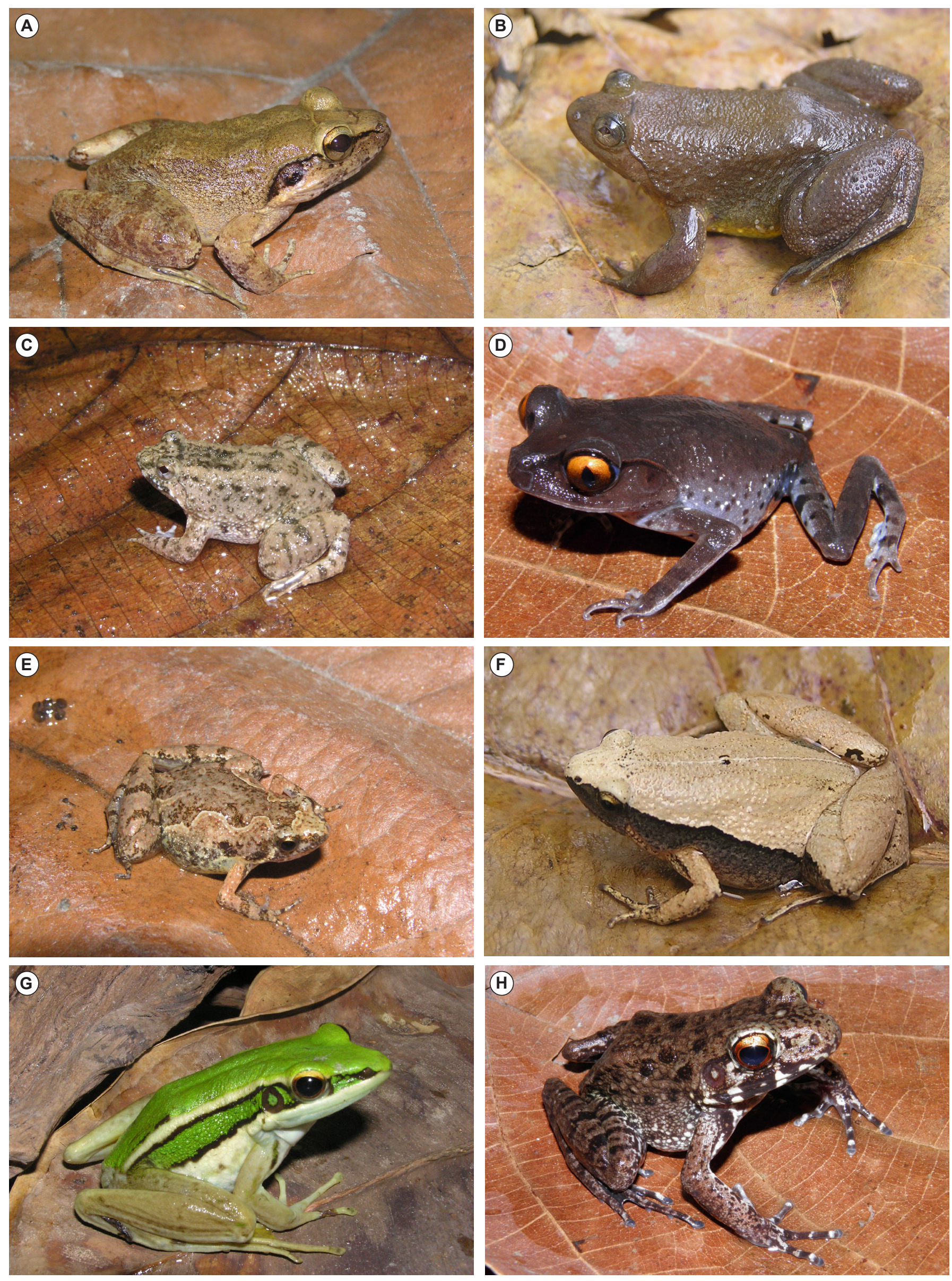

FiguRE 3. Some amphibian species found at Ulu Paip, Kedah. A) Limnonectes paramacrodon; B) Occidozyga laevis; C) Occidozyga martensii; D) Leptobrachium hendricksoni; E) Microhyla butleri; F) Microhyla heymonsi; G) Hylarana erythraea; H) Hylarana glandulosa. 

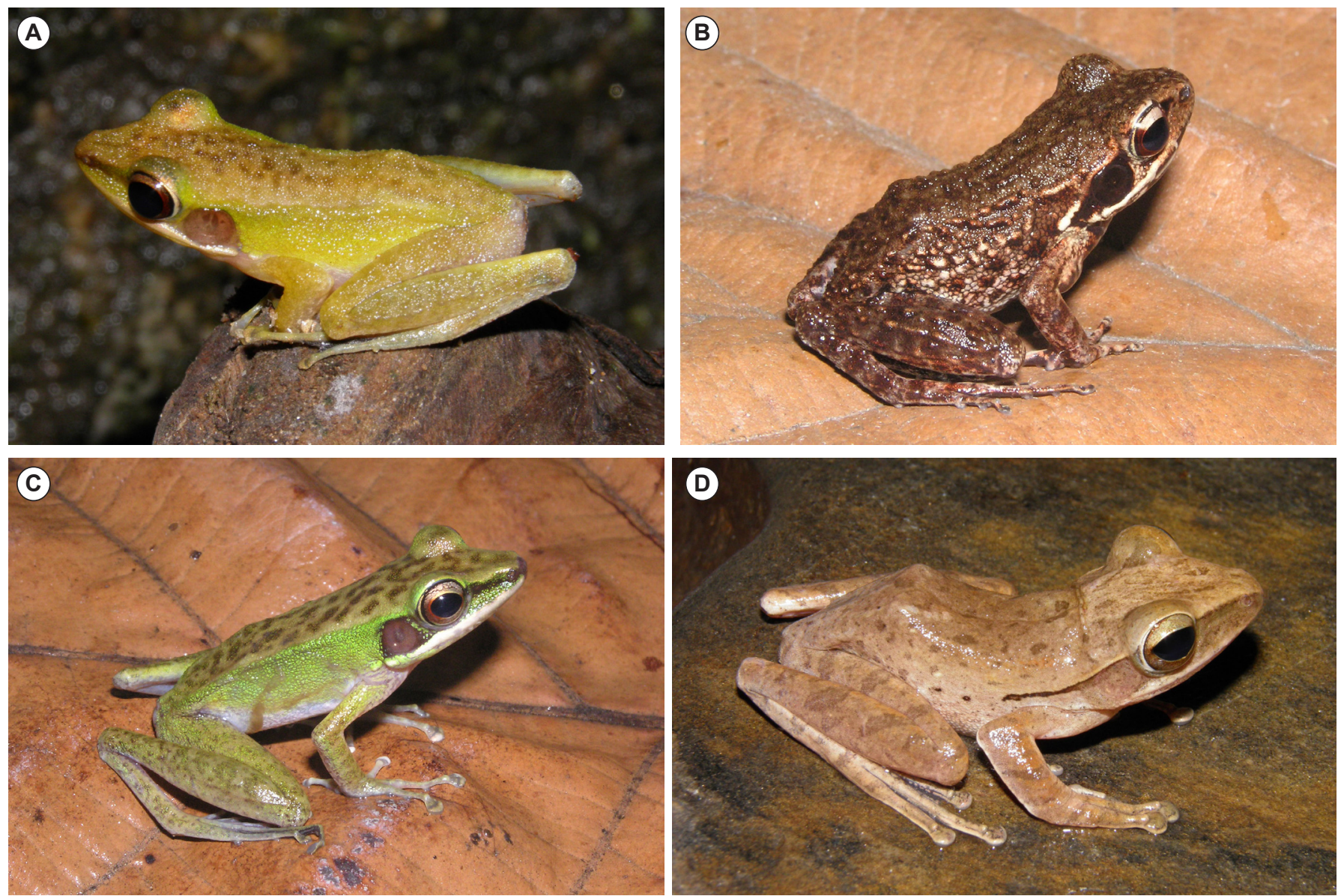

FIGURE 4. Some amphibian species found at Ulu Paip, Kedah. A) Hylarana labialis; B) Hylarana laterimaculata; C) Hylarana nicobariensis; D) Polypedates leucomystax.

\section{Species Account}

\section{Family Bufonidae}

Duttaphrynus melanostictus (Schneider, 1799) (Figure 2A)

An amplectant pair was observed in December 2011 in a shallow temporary pool (8-12 $\mathrm{cm}$ deep) beside the road along the way to Ulu Paip after heavy rain. Two other males were also observed calling at the same site. They match the description of this species in having a stout body, supraorbital bony ridges, absence of parietal ridges and elongated parotoid gland (more than twice as long as wide) (Berry, 1975).

\section{Ingerophrynus parvus (Boulenger, 1887) (Figure 2B)}

An adult male (11USM-UP-IP01) was captured in October 2011 perched on rotten wood near a shallow temporary puddle at the edge of a forest stream. It is in accord with Berry's (1975) description of this species in having triangular or oval parotoid gland and this gland is not followed by enlarged warts.

\section{Pedostibes hosii (Boulenger, 1892) (Figure 2C)}

Several males were actively calling in January, March, November and December 2011 but none were heard or observed during other months. In January 2011, four males were heard calling around a small forest stream near the main river. One adult (11USM-UP-PH01) was collected perched on tree branch approximately $1.5 \mathrm{~m}$ above ground. It matches the diagnosis of this species in having a moderately stout body, tips of fingers dilated into broad, truncate disks and first finger with at least two joints free of web (Berry, 1975).

\section{Phrynoidis aspera (Gravenhorst, 1829) (Figure 2D)}

This common toad was found every month during the sampling period. Individuals were frequently observed on or under big rocks, boulders or fallen logs near the river or adjacent streams. Sometimes toads can be found perched on tree branches (ca. 1-2 m above ground) and also in the public toilet. An average of seven to ten individuals were encountered during each visit. They resemble the description of this species in having a stout body, head wider than long, supraorbital bony ridges, no parietal ridges and round to triangular parotoid gland but never twice as long as wide (Berry, 1975).

\section{Family Dicroglossidae}

Fejervarya cancrivora (Gravenhorst, 1829) (Figure 2E)

An adult was observed in May 2011 in a ditch with shallow water and another one in August 2011 near the edge of a small stream. They match the description of this species in having several characteristics such as web not reaching tips of all toes, back with many distinct longitudinal ridges and throat variably marbled with light and darker colour (Berry, 1975).

\section{Fejervarya limnocharis (Gravenhorst, 1829) (Figure 2F)}

We found this species in every month during the survey period. Usually this species was encountered near the car park, in ditches and around temporary puddles. 
In November 2011, two amplectant pairs were sighted in a shallow puddle beside the road after evening shower. Several other males were observed calling at the same site and two individuals (11USM-UP-FL01, 02) were captured as voucher specimens. These specimens are in accord with Berry's (1975) description of this species in having several characteristics such as the present of small outer metatarsal tubercles, tips of toes blunt or pointed, not expanded and broad webbing usually not extending beyond middle tubercle of fourth toe.

\section{Limnonectes blythii (Boulenger, 1920) (Figure 2G)}

A single adult (11USM-UP-LB01) was captured in May 2011 while hiding under a big rock at the edge of the river. It is in accord with Berry's (1975) description of this species in having a longer head than broad, snout rounded to rather pointed, tympanum distinct, dark temporal spot not covering entire tympanum, web reaching disks of 2 nd and 3 rd toes on both sides and males with fang like processes on lower jaw.

\section{Limnonectes laticeps (Boulenger, 1882) (Figure 2H)}

Two individuals (11USM-UP-LL01, 02) were caught in March 2011 perched on tree roots at the edge of a small forest stream. They match the diagnosis of this species in having several characteristics such as tympanum not visible through skin, toes not fully webbed to disks, no freely movable flap of skin along fifth toe and skin of lower leg smooth without conspicuous spiny tubercles (Berry, 1975).

\section{Limnonectes paramacrodon (Inger, 1966) (Figure 3A)}

An adult (11USM-UP-LP01) was collected in February 2011 while hiding beside tree buttress near a muddy swamp. Several other species such as Occidozyga laevis, Hylarana glandulosa and H. laterimaculata were also sighted around this swamp. It matches the description of this species in having a smooth or with sparse tubercles on dorsal skin and a dark temporal spot covering the entire tympanum (Berry, 1975).

\section{Occidozyga laevis (Gunther, 1858) (Figure 3B)}

Several specimens were sighted in July 2011 halfimmersed in a muddy swamp but only two individuals (11USM-UP-OL01, 02) were collected as vouchers. These specimens are in accord with Berry's (1975) description of this species in having several characteristics such as tongue broadly rounded at tip, toe tips usually expanded into disks and have a smooth belly.

\section{Occidozyga martensii (Peters, 1867) (Figure 3C)}

One individual (11USM-UP-OM01) was captured in July 2011 in a small puddle filled with dead leaves beside a road. This specimen is in accord with description of this species by Norhayati et al. (2009) in having indistinct tympanum and smooth skin with rounded warts near the vent, flanks and limbs.

\section{Family Megophryidae}

Leptobrachium hendricksoni Taylor, 1962 (Figure 3D)

One specimen (11USM-UP-LH01) was collected in July
2011 sitting on wet forest floor and another one (11USMUP-LH02) was caught in October 2011 hiding among leaf litter near a small forest stream. They match the diagnosis of this species in having a broad head, snout rounded, tympanum distinct, a supratympanic fold from eye to axilla, ventral surface with large or small black dots and red iris (Taylor, 1962).

\section{Family Microhylidae}

Microhyla butleri Boulenger, 1900 (Figure 3E)

An adult (11USM-UP-MB01) was collected in May 2011 while hiding under stone beside a road. This specimen resemble the description of this species in having several characteristics such as no dark lateral bands or black marks in middle of the back and back with symmetrical pattern of large wavy markings which extend down onto sides (Berry, 1975).

\section{Microhyla heymonsi Vogt, 1911 (Figure 3F)}

An amplectant pair was observed in August 2011 in a shallow temporary puddle near a ditch after heavy rains. We also heard many males actively calling around this area. They are in accord with Berry's (1975) description of this species in having a prominent dark band with contrasting light upper edges running down side of body from snout to inguinal region and a pair of small black marks in the middle of the back.

\section{Family Ranidae \\ Hylarana erythraea (Schlegel, 1837) (Figure 3G)}

An adult was spotted in April 2011 perched on tree twig (approx. $20 \mathrm{~cm}$ above ground) adjacent to the ditch. It is match the description of this species in having two broad and light longitudinal stripes on dorsum and no longitudinal lines on femur (Berry, 1975).

\section{Hylarana glandulosa (Boulenger, 1882) (Figure 3H)}

We heard the sound of this species in April, May, September, November and December 2011. Several males were actively calling from the swampy areas and ditches near the main river. These activities started as early as 17:30 until 19:30 h.

\section{Hylarana labialis (Boulenger, 1887) (Figure 4A)}

An adult (11USM-UP-HLab01) was captured in June 2011 while sitting on leaves (approx. $20 \mathrm{~cm}$ above ground) at the edge of a small forest stream. This specimen is in accord with Berry's (1975) description of this species in having large finger disks and a small outer metatarsal tubercle on foot.

\section{Hylarana laterimaculata (Barbour \& Noble, 1916) (Figure 4B)}

Two individuals were encountered in September 2011 perched on fern twigs (approx. $30 \mathrm{~cm}$ above ground) near a swampy area. Only a single individual (11USMUP-HLat01) was collected as a voucher specimen. It is in accord with Berry's (1975) description of this species in having small or large flat glandular tubercles which may be more distinct on the sides than on the back and having a little extending web beyond outer tubercle of fifth toe. 
Hylarana nicobariensis (Stoliczka, 1870) (Figure 4C)

An adult was sighted in October 2011 resting on dead wood (approx. $20 \mathrm{~cm}$ above ground) near a ditch. It matches the description of this species in having pale gland on upper arm and located distally near bend of elbow (Berry, 1975).

\section{Family Rhacophoridae}

Polypedates leucomystax (Gravenhorst, 1829) (Figure 4D)

An amplectant pair was observed in November 2011 sitting on dead leaves near a temporary puddle beside the road after evening shower. They are in accord with diagnosis of this species by Berry's (1975) in having rounded snout tip, smooth heel without conicle tubercle and back often with four longitudinal stripes.

\section{Discussion}

Twenty species of frogs were found to inhabit Ulu Paip Recreational Forest and this number is comparable to other sampling sites in Kedah. In Gunung Inas Forest Reserve (18 km from Ulu Paip), 28 species of amphibians were recorded (Ibrahim et al. 2012a) while at Lata Bukit Hijau (55 km from Ulu Paip), 18 species of amphibians were recorded (Shahriza et al. 2011b). Other locations in Kedah such as Beris Valley (Shahriza et al. 2011a), Gunung Jerai (Ibrahim et al. 2006) and Bukit Perangin (Ibrahim et al. $2012 \mathrm{~b}$ ) recorded 14,14 and 15 species of amphibians respectively.
Six commensal species which are Duttaphrynus melanostictus, Fejervarya limnocharis, Microhyla butleri, Microhyla heymonsi, Hylarana erythraea and Polypedates leucomystax and 14 forest frogs which are Ingerophrynus parvus, Pedostibes hosii, Phrynoidis aspera, Fejervarya cancrivora, Limnonectes blythii, Limnonectes laticeps, Limnonectes paramacrodon, Occidozyga laevis, Occidozyga martensii, Leptobrachium hendricksoni, Hylarana glandulosa, Hylarana labialis, Hylarana laterimaculata and Hylarana nicobariensis were found in Ulu Paip forest. According to Inger (2005) commensal species live in severely disturbed environments, environments directly associated with the activities of man. All of these species breed in ponds and are rarely if ever found in forests. In Ulu Paip, all the commensal species were encountered near or in the temporary puddles and ditches beside the road (disturbed areas) and not found in the forest. The remaining 14 species are common forest frogs that live in lowland dipterocarp forest of Peninsular Malaysia. In Ulu Paip, we sighted these species in the forest or at the edge of the forest (undisturbed areas). Some secretive forest species such as $P$. hosii, L. paramacrodon and $H$. laterimaculata were also encountered here. The presence of swampy areas with stagnant water in Ulu Paip forest provided an ideal breeding site for H. laterimaculata while small forest streams with slow moving currents are ideal sites for P. hosii and L. paramacrodon. According to Inger and Stuebing (1989), P. hosii lives in primary forest and

TABLE 1. Amphibians of Ulu Paip Recreational Forest, Kedah.

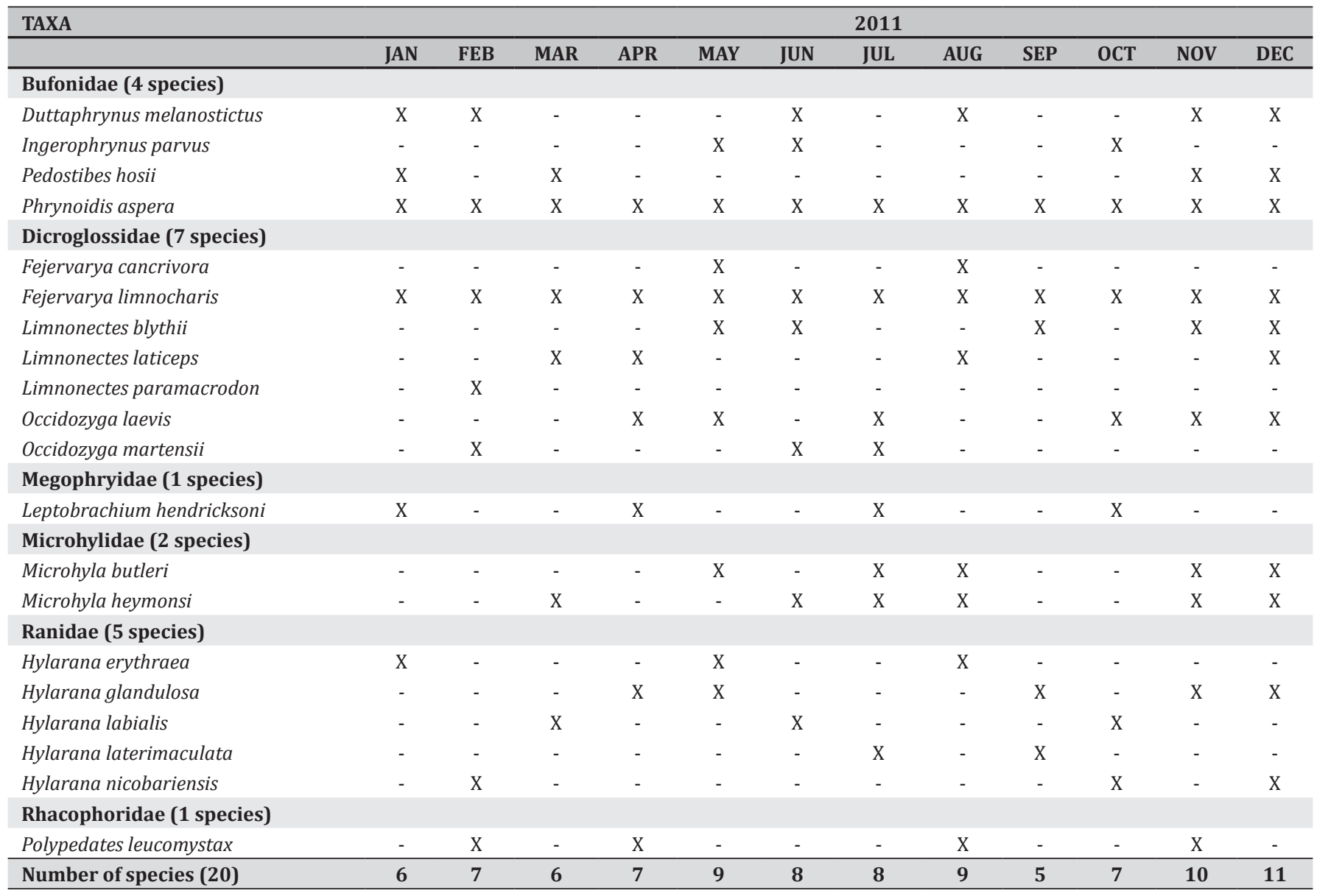

- $=$ Absence

$\mathrm{X}=$ Presence 
comes to medium-sized clear streams to breed. Their tadpoles live in side pools and in accumulations of dead leaves in these streams. Additionaly other record shows that $P$. hosii can be found in the forest and other dense vegetation along large lowland rivers and breeding takes place in a clear forest streams (IUCN, 2013). As for L. paramacrodon, this species prefers small streams in primary and selectively logged, lowland rain forest to breed (Inger \& Stuebing, 1989). However, we only spotted the presence of $P$. hosii in January, March, November and December 2011, H. laterimaculata in July and September 2011 and L. paramacrodon only in February 2011.

Most parts of the forest in Ulu Paip have been transformed into farms, orchards, rubber and oil palm plantations. As a result, various microhabitats such as leaf litter, rotten logs, tree buttress, tree holes, shrubs and bushes have been destroyed. Breeding sites such as swamps, freshwater marshes, small creeks and ditches become dry due to increase light intensity. These phenomena will affect the population of frog species and some species that cannot survive in a new environment will die. On the other hand, the use of pesticide and herbicide in the agricultural areas also affected the survival of the frog species. To protect the frog species in Ulu Paip, the government especially the Forestry Department should monitor or stop the agriculture activities in this area.

ACKNOWLEDGMENTS: We wish to express our heartfelt gratitude to Universiti Sains Malaysia, Penang for all the facilities and amenities provided. Also thank you to all our friends, colleagues and everyone who were involved in this project. This research project was supported by Universiti Sains Malaysia, Short Term Grant No. 304/PFARMASI/638161 to the first author and Research University Grant No. 1001/ PJJAUH/815030 to the second author.

\section{Literature Cited}

Berry, P.Y. 1975. The Amphibian Fauna of Peninsular Malaysia. Kuala Lumpur: Tropical Press. 133 pp.
Frost, D. 2012. Amphibia Species of the World. Accessible at http:// research.amnh.org/vz/herpetology/amphibia. Captured on 20 March 2013.

Ibrahim, J., I. Wong, A.S. Nur Ziana, Y. Khoo and I. Ayyub. 2006. Relative Abundance, Density and Distribution of Amphibian Species on Gunung Jerai; pp. 419-426, in: S.M. Ismail, W.Y.W. Ahmad, J. Md Som, Y. Muda and A. Latiff Mohamad (ed.). Hutan Simpan Gunung Jerai, Kedah: Pengurusan, Persekitaran Fizikal dan Kepelbagaian Biologi. Kuala Lumpur: Jabatan Perhutanan Semenanjung Malaysia.

Ibrahim, J., I. Nur Hafizah, A.R. Nurul Dalila, T. Choimmber and M.A. Abdul Muin. 2012a. Amphibian Biodiversity of Gunung Inas Forest Reserve, Kedah, Malaysia. Pertanika Journal of Tropical Agriculture Science. 35(2): 249-256.

Ibrahim, J., A. Zalina, S. Shahriza, M.S. Shahrul Anuar, I. Nur Hafizah, H. Amirah, A.R. Nurul Dalila, M.A. Abdul Muin and I. Amirudin. 2012b. Checklist of the Herpetofauna of Bukit Perangin Forest Reserve, Kedah, Malaysia. Sains Malaysiana. 41(6): 691-696.

Inger, R.F. 2005. The Frog Fauna of the Indo-Malayan Region as it Applies to Wallace's Line; pp. 82-90, in: A.A. Tuen and I. Das (ed.). Wallace in Sarawak-150 Years Later. An International Conference on Biogeography and Biodiversity. Kota Samarahan: Institute of Biodiversity and Environmental Conservation, Universiti Malaysia Sarawak. 82-90.

Inger, R.F. and R.B.Stuebing. 1989. Frogs of Sabah. Kota Kinabalu: Sabah Parks Trustees. 129 pp.

IUCN 2013. The IUCN Red List of Threatened Species Version 2013.2 Accessible at http://www.iucnredlist.org. Captured on 25 November 2013.

Norhayati, A., S. Juliana and B.L. Lim. 2005. Amphibians of Ulu Muda Forest Reserve, Kedah. Kuala Lumpur: Forestry Department of Peninsular Malaysia. 120 pp.

Norhayati, A., B. Daicus and K.O. Chan. 2009. Amphibia My: Amphibians and Reptiles of Peninsular Malaysia. Accessible at http://amphibia. my. Captured on 25 October 2013.

Shahriza, S., J. Ibrahim, A.R. Nurul Dalila and M.A. Abdul Muin. 2011a. An Annotated Checklist of the Herpetofauna of Beris Valley, Kedah, Malaysia. Tropical Life Sciences Research 22(1): 13-25.

Shahriza, S., J. Ibrahim and M.S. Shahrul Anuar. 2011b. The Amphibian Fauna of Lata Bukit Hijau, Kedah, Malaysia. Russian Journal of Herpetology. 18(3): 221-227.

Taylor, E.H. 1962. The Amphibian Fauna of Thailand. University of Kansas Science Bulletin 43: 267-599.

RECEIVED: October 2013

ACCEPTED: February 2014

Published online: May 2014

EDITORIAL RESPONSIBILITY: Perry Lee Wood Jr 